\title{
Changes in Air Temperature and Snow Cover in Winter in Poland
}

\author{
Arkadiusz M. Tomczyk (D), Ewa Bednorz *(D) and Katarzyna Szyga-Pluta (D)
}

check for updates

Citation: Tomczyk, A.M.; Bednorz, E.; Szyga-Pluta, K. Changes in Air Temperature and Snow Cover in Winter in Poland. Atmosphere 2021, 12 68. https://doi.org/10.3390/atmos 12010068

Received: 8 December 2020 Accepted: 31 December 2020 Published: 5 January 2021

Publisher's Note: MDPI stays neutral with regard to jurisdictional clai$\mathrm{ms}$ in published maps and institutional affiliations.

Copyright: (C) 2021 by the authors. Licensee MDPI, Basel, Switzerland. This article is an open access article distributed under the terms and conditions of the Creative Commons Attribution (CC BY) license (https:// creativecommons.org/licenses/by/ $4.0 /)$.
Department of Meteorology and Climatology, Adam Mickiewicz University in Poznań, 61-712 Poznań, Poland; atomczyk@amu.edu.pl (A.M.T.); pluta@amu.edu.pl (K.S.-P.)

* Correspondence: ewabedno@amu.edu.pl; Tel.: +48-61-829-6267

\begin{abstract}
The primary objective of the paper was to characterize the climatic conditions in the winter season in Poland in the years 1966/67-2019/20. The study was based on daily values of minimum (Tmin) and maximum air temperature (Tmax), and daily values of snow cover depth. The study showed an increase in both Tmin and Tmax in winter. The most intensive changes were recorded in north-eastern and northern regions. The coldest winters were recorded in the first half of the analyzed multiannual period, exceptionally cold being winters 1969/70 and 1984/85. The warmest winters occurred in the second half of the analyzed period and among seasons with the highest mean Tmax, particularly winters 2019/20 and 1989/90 stood out. In the study period, a decrease in snow cover depth statistically significant in the majority of stations in Poland was determined, as well as its variability both within the winter season and multiannual.
\end{abstract}

Keywords: air temperature; snow cover depth; winter; climate change; Poland

\section{Introduction}

The currently observed climate warming raises no doubts, and the first decade of the 21st century is recognized as the warmest in the history of instrumental measurements [1]. It is estimated that human activity caused global warming approximately $1.0^{\circ} \mathrm{C}$ above the level from before the industrial age, with a probable range from $0.8^{\circ} \mathrm{C}$ to $1.2{ }^{\circ} \mathrm{C}$ [2] Further increase in air temperature is forecasted for the following decades. According to the IPCC report [3] and other research, temperature will grow faster in winter than in the remaining seasons, particularly in far future (2071-2100), according to scenario RCP8.5 by more than $1^{\circ} \mathrm{C}[4,5]$.

Warming more intense than the global average is observed in many terrestrial regions in different seasons, which is followed by extreme records in recent years. For example the boreal winter season $2019 / 2020$ was warmest in the history of measurements, with mean temperature higher by $1.4{ }^{\circ} \mathrm{C}$ in comparison to the warmest winter so far in 2015/2016. In Europe rapid changes are observed and an increase in temperature has been the most evident in the north of the continent [6]. In central and north Europe, an increase in extreme temperature values is considerably higher than the corresponding average winter warming, and approximately 2.5 times higher than average global warming [7].

Changes in temperature in Poland correspond with changes in thermal conditions throughout central Europe [8]. In Poland, the strongest increase in temperature is observed in spring and summer [9-11] and the observed warming, is strongly manifested in a decrease in the frequency of occurrence of cold days and cold waves [12-16]. According to Koenigk et al. [17], winter temperatures are correlated the strongest with the variability of marine ice around Greenland. Ziernicka-Wojtaszek and Zuśka [18] estimate that in the future, one in five winters in Poland will show positive mean areal air temperature in all months, and the most important negative effect of occurrence of warm winters is reduction of the duration and thickness of snow cover. 
Snow cover is most sensitive to changes in temperature and precipitation and therefore it is considered a good indicator of climate change. European snow cover is primarily determined by air temperature. The effect of precipitation on the snowpack is less obvious, primarily because the snowfall/rainfall ratio is strongly controlled by air temperature [19]. The relationship between snow cover and other climatic elements strongly depends on geographic location, latitude, and elevation $[20,21]$. An increase in temperature has decreased snow accumulation, and reduced snow cover duration at mid-latitudes and mid- and low elevations, and not in the coldest regions, e.g., [21-25].

The temperature-snow cover relationship activates one of the strongest climate change feedback as snow, due to its high albedo, strongly modifies surface-atmosphere energy fluxes [26]. An increase in temperature results in the diminishment of snow cover and on the other hand, decrease in the range of snow cover is considered as the primary cause of strong temperature increase in winter in eastern Europe $[27,28]$. Differences in the range of snow cover in Europe probably contribute to the occurrence of warm and cold days in winter [29]. A correlation exists between the tendency for decrease in the range of snow cover in Europe and the growing (decreasing) trend of the number of warm (cold) days throughout Europe.

Large scale studies concerning snow cover duration have predominantly recognized declining trends in the Northern Hemisphere, with the most intense reduction since the 1980s, e.g., [22,30,31]. Lowland areas of central and northern Europe are characterized by the reduction of cover duration [32,33], although a simultaneous tendency of an increase in snow cover depth has been recorded [33,34]. In Poland, however, only a slight decreasing trend of snow cover characteristics was detected in the second half of the 20th century [32,35-39]. High variability between individual seasons and an increasing frequency of mild and snowless winters occurring in a moderate climate zone was also emphasized, e.g., [40,41]. The occurring slight discrepancy between the current general ideas concerning snow cover tendency, namely the expectations of a strongly declining trend, and results of previous studies covering the second half of the 20th century, make the research of the contemporary changes in winter snow cover in Poland a relevant issue.

Further diminishing of seasonal snow cover is expected in Europe in accordance with climatic projections [42,43]. The projections suggest a reduction of maximum snow cover thickness by approximately $-15 \%$ and approximately $-20 \%$ for RCP 4.5 and RCP 8.5 , respectively, by the period 2021-2050. The reductions will double by the period 2071-2100 irrespective of RCP, and may reach up to $-40 \%$ according to RCP8.5 [44]. The variability of snow cover thickness in the second half of the 20th century increased from year to year, and it was spatially variable in Poland [35]. According to research by Piotrowski and Jẹdruszkiewicz [45], thermal conditions of winters and snow cover in Poland have been and in the foreseeable future (2021-2050) will be closely related to atmospheric circulation.

At European mid-latitudes, long-term changes in winter weather conditions are partly modulated by short-term fluctuations associated with the variability of atmospheric circulation $[24,46]$. The leading role of the predominant winter teleconnection pattern over the Euro-Atlantic region, i.e., North Atlantic Oscillation (NAO) as a driving factor has been emphasized in previous studies, i.e., [24,47-50]. Therefore, although the increasing tendency of air temperature and the declining tendency of snow cover is projected in Poland under the warming climate, a large inter-winter variability can still be expected, due to the overlapping impact of circulation conditions.

Central Europe has experienced several mild winters since the 1990s. Last winter $2019 / 2020$, extremely warm and snowless, was one of the motivations to undertake this study. The primary objective of the paper was to characterize the climatic conditions in the winter season in Poland in the years 1966/67-2019/20. The implementation of the primary study objective involved: (1) analysis of the temporal and spatial variability of thermal conditions in winter, and (2) occurrence of snow cover, as well as (3) determination of the effect of atmospheric circulation on thermal and nival conditions in winter. 


\section{Data and Study Methods}

The study was based on daily values of minimum (Tmin) and maximum air temperature (Tmax), and daily values of snow cover depth. The data were obtained from the Institute of Meteorology and Water Management-National Research Institute for 40 stations in Poland from the period 1966/67-2019/20, whereas 31 of the stations had a complete data set concerning snow cover for the discussed observation period (Figure 1). The winter season was defined as a sequence of three months from December to February.

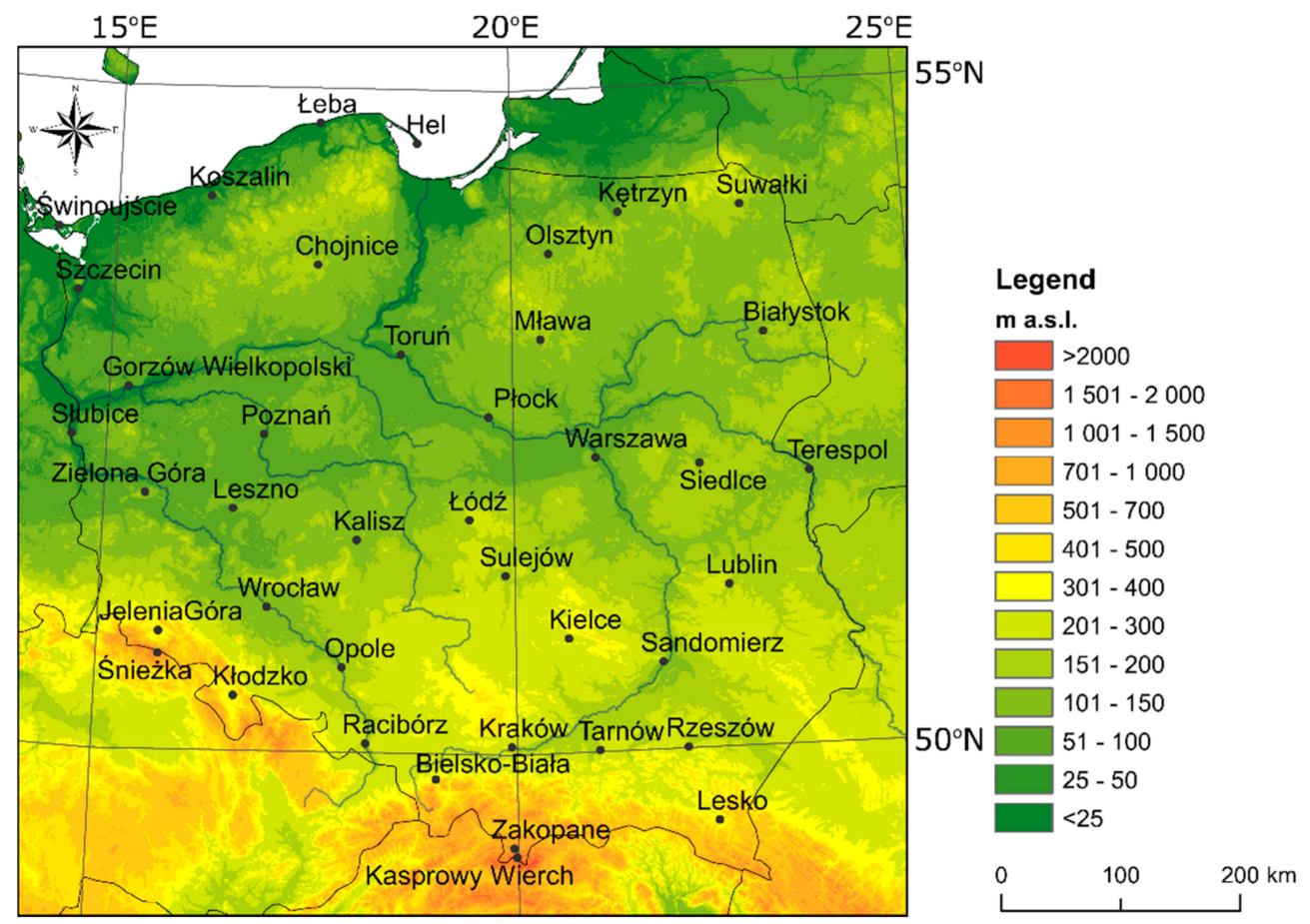

Figure 1. Location of stations.

First, the obtained data provided the basis for the calculation of mean Tmin and Tmax in particular winter months and seasons. Based on these data, seasons and months with the lowest mean Tmin and highest mean Tmax were determined, showing the range of fluctuations of thermal conditions in winter. Then, the direction of changes in mean Tmin and Tmax was analyzed, and the statistical significance of the observed changes was determined $(p<0.05, p<0.01, p<0.001)$. The assessment of the trend of changes employed linear regression, and the significance of trends was verified by means of a t-Student test. Daily data provided the basis for the determination of days with the lowest Tmin and highest Tmax in the analyzed multiannual period. Tmin and Tmax anomalies were also calculated for the selected winter seasons. The anomalies were calculated as the difference between mean air temperature value in a particular season, and mean value in the season in the analyzed years.

Analogically, multiannual changes in characteristics of snow cover were analyzed, as well as their anomalies for selected extreme winters. This employed the basic properties of snow cover, i.e., number of days with snow cover during winter defined as the months of December, January, and February, and mean snow cover depth calculated only for days of its occurrence. Anomalies were calculated similarly as in the case of air temperatures.

The determination of circulation conditions employed two macroscale circulation types, i.e., North Atlantic Oscillation (NAO) and Scandinavian pattern (SCAND). As found in earlier studies, these types have the strongest effect on the climatic and weather conditions in central Europe, including Poland [51,52]. Monthly values of the NAO and SCAND indices were obtained from the data bases of Climate Prediction Centre NOAA. 
The NAO is a bipolar circulation type resulting from the co-occurrence of the Azores High and Icelandic Low. The type is characterized by two phases, positive and negative. In the first case, lower than average air pressure is recorded in the center of the Icelandic Low, and higher in the Azores High. The co-occurrence of higher than average pressure in the Icelandic Low and lower in the Azores High constitutes the negative NAO phase $[53,54]$. In the positive phase, NAO brings mild winters in central Europe, and in the negative phase cold and snowy winters [55-57].

The SCAND pattern is characterized by the occurrence of a strong high pressure system over the Scandinavian Peninsula. Simultaneously, an area of lower than average pressure extends from western Europe to eastern Russia/western Mongolia. In the positive phase, pressure is higher than average, sometimes creating a blockade situation over Scandinavia and western Russia. The negative phase is related to lower than average pressure over northern Europe [58-61].

The aforementioned data provided the basis for the calculation of the Pearson correlation coefficient between mean winter NAO and SCAND index and mean Tmin and Tmax, as well as analysis of statistical significance at levels of $p<0.05, p<0.01$, and $p<0.001$. Then, statistical significance of the difference in temperature between Tmin and Tmax was calculated for the positive and negative NAO and SCAND phase. This stage covered years in which the index value was below the first and above the third quartile from the analyzed years. The determination of statistical significance employed test $t$ for independent samples, and like above, three significance thresholds were applied. Moreover, the difference in temperature was calculated (respectively for Tmin and Tmax) between the negative and positive phase of the selected indices. Analogical procedures were applied for the winter number of days with snow cover, comparing the permanence of the snow cover in years characterized by the occurrence of a positive and negative phase of both considered circulation types.

The mathematical and statistical processing of analysis results employed statistical procedures included in MS Excel. QGIS and Surfer software was used to visualize the obtained results.

\section{Results}

\subsection{Air Temperature}

In winter in the years $1966 / 67-2019 / 20$, mean Tmin and Tmax in Poland were $-3.9^{\circ} \mathrm{C}$ and $1.6^{\circ} \mathrm{C}$, respectively, and increased from the north-east to the south-west and west of the country (Figure 2). Such a spatial distribution was disturbed in mountain areas, where the factor changing thermal conditions is land elevation above sea level. The lowest mean Tmin and Tmax were recorded in stations located at the highest elevations, i.e., on Kasprowy Wierch $\left(-10.1{ }^{\circ} \mathrm{C}\right.$ and $-4.7^{\circ} \mathrm{C}$, respectively) and Śnieżka $\left(-8.3^{\circ} \mathrm{C}\right.$ and $-3.4^{\circ} \mathrm{C}$, respectively). Outside of mountain areas, the lowest mean Tmin and Tmax were recorded in the north-east of the country with a minimum in Suwałki $\left(-5.8^{\circ} \mathrm{C}\right.$ and $-0.8^{\circ} \mathrm{C}$, respectively), and the highest values were observed in the west and north of the country, i.e., mean Tmin in $\mathrm{Hel}\left(-1.1^{\circ} \mathrm{C}\right)$, and Tmax in Stubice $\left(3.7^{\circ} \mathrm{C}\right)$. In the analyzed multiannual period, throughout the area, an increase in both Tmin and Tmax was recorded. The observed changes over the study area were statistically significant (Table 1; Figure 3). In both cases, the greatest changes were observed in north-eastern and northern Poland. The greatest increase in Tmin and Tmax was recorded in Suwałki. It was $0.70{ }^{\circ} \mathrm{C} / 10$ years and $0.57^{\circ} \mathrm{C} / 10$ years, respectively. Moreover, changes in Tmin at a level of $\geq 0.50{ }^{\circ} \mathrm{C} / 10$ years were also recorded in Białystok, Chojnice, Kętrzyn, Koszalin, Mława, Olsztyn, Rzeszów, Siedlce, Szczecin, Terespol, and Warszawa. Changes in Tmax at a level of $\geq 0.50{ }^{\circ} \mathrm{C} / 10$ years were recorded in Kętrzyn, Suwałki, Szczecin, and Terespol. In the majority of stations (i.e., in 26 out of 40 stations), changes in Tmin were higher than changes in Tmax, and the greatest differences in the increase occurred in the east, and particularly in the south-east of the country. 

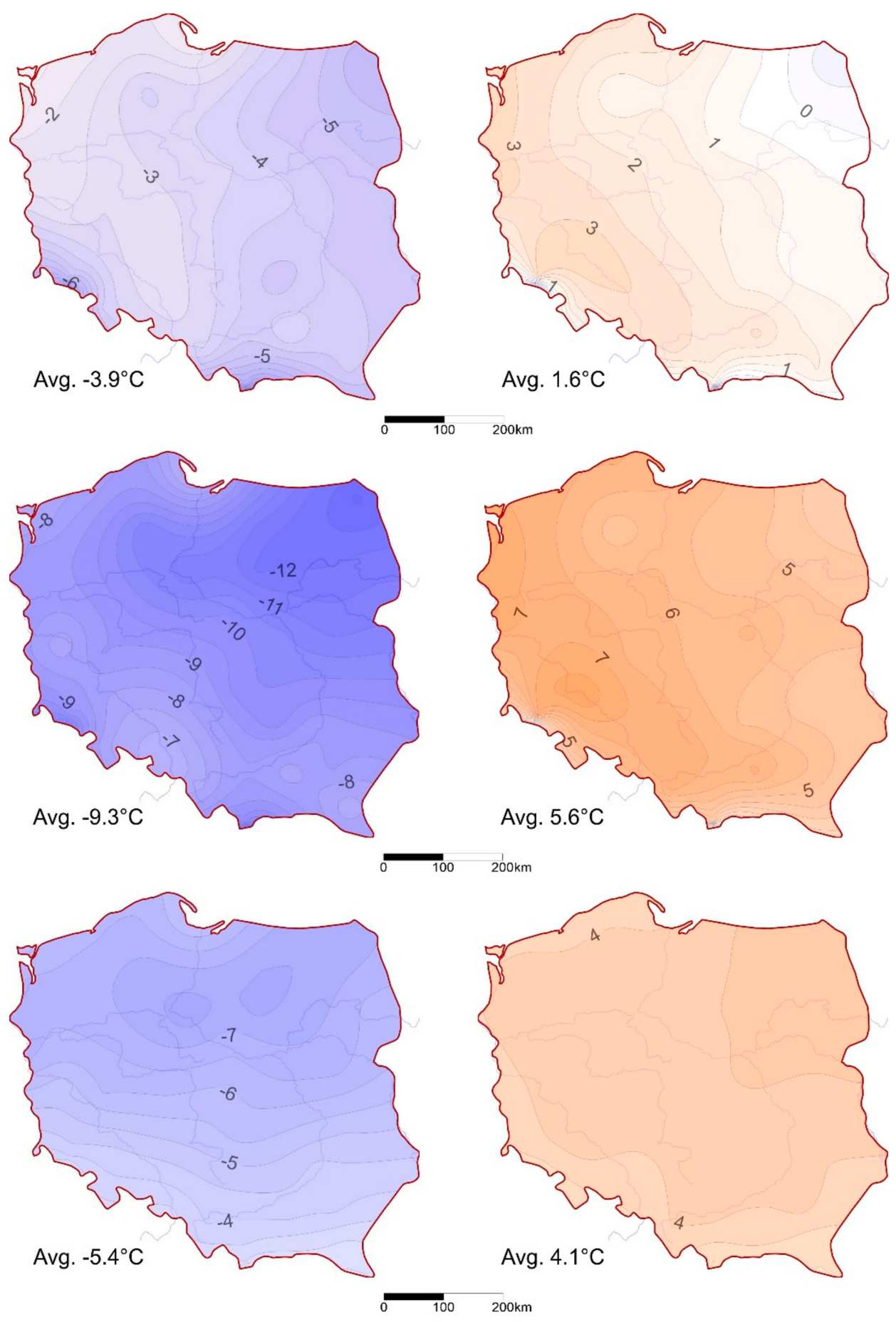

Figure 2. Mean Tmin and Tmax in winter in the years 1966/67-2019/20 (top row), mean Tmin and Tmax in winter of (respectively) 1969/70 and 2019/20 (middle row), and Tmin and Tmax anomalies during those winters (bottom row). Left column-Tmin, right column-Tmax.

In the analyzed multiannual period, very high variability of thermal conditions in the winter season was observed in Poland. In the majority of stations (in 23 out of 40 stations), the coldest winter was recorded in the season $1969 / 70$ with mean Tmin of $-9.3{ }^{\circ} \mathrm{C}$ for the entire area (Table 1). An increase in mean Tmin occurred from the north-east to the south and west of the country, and along the coast (Figure 2). In particular stations, mean Tmin values varied from $-13.1{ }^{\circ} \mathrm{C}$ in Suwałki to $-6.1^{\circ} \mathrm{C}$ in Hel. In the analyzed season, in stations located the highest, mean Tmin was $-11.9^{\circ} \mathrm{C}$ on Kasprowy Wierch and $-11.3^{\circ} \mathrm{C}$ on Śnieżka. During that winter, mean Tmin was lower than average in the multiannual 
period from $1.9^{\circ} \mathrm{C}$ on Kasprowy Wierch to $7.8^{\circ} \mathrm{C}$ in Torun. In the remaining stations (in 17 out of 40 stations), the coldest winter was recorded in season 1984/85.

Table 1. Characteristics of thermal conditions in winter in the years 1966/67-2019/20. Stations are arranged in spatial order from the north to the south.

\begin{tabular}{|c|c|c|c|c|c|c|c|c|c|}
\hline \multirow[t]{2}{*}{ Station } & \multicolumn{2}{|c|}{$\begin{array}{c}\text { Changes }\left({ }^{\circ} \mathrm{C} / 10\right. \\
\text { Years) }\end{array}$} & \multirow{2}{*}{$\begin{array}{l}\text { Coldest } \\
\text { Season }\end{array}$} & \multirow{2}{*}{$\begin{array}{c}\text { Warmest } \\
\text { Season }\end{array}$} & \multirow[t]{2}{*}{ Station } & \multicolumn{2}{|c|}{$\begin{array}{c}\text { Changes }\left({ }^{\circ} \mathrm{C} / 10\right. \\
\text { Years) }\end{array}$} & \multirow{2}{*}{$\begin{array}{l}\text { Coldest } \\
\text { Season }\end{array}$} & \multirow{2}{*}{$\begin{array}{c}\text { Warmest } \\
\text { Season }\end{array}$} \\
\hline & Tmin & Tmax & & & & Tmin & Tmax & & \\
\hline Leba & 0.48 & 0.39 & $1969 / 70$ & $2019 / 20$ & Leszno & 0.41 & 0.43 & $1969 / 70$ & $2019 / 20$ \\
\hline Hel & 0.44 & 0.38 & $1969 / 70$ & $2019 / 20$ & Kalisz & 0.47 & 0.40 & $1969 / 70$ & $2019 / 20$ \\
\hline Koszalin & $\underline{0.54}$ & 0.45 & $1969 / 70$ & $2019 / 20$ & Łódź & 0.42 & 0.44 & $1969 / 70$ & $2019 / 20$ \\
\hline Suwałki & $0.70 *$ & $\underline{0.57}$ & $1969 / 70$ & $2019 / 20$ & Sulejów & 0.46 & 0.41 & $1984 / 85$ & $2019 / 20$ \\
\hline Kętrzyn & 0.55 & 0.50 & $1969 / 70$ & $2019 / 20$ & Lublin & 0.47 & 0.34 & $1984 / 85$ & $2019 / 20$ \\
\hline Świnoujście & 0.42 & 0.43 & $1969 / 70$ & $2019 / 20$ & Wrocław & 0.46 & 0.48 & $1984 / 85$ & $2019 / 20$ \\
\hline Olsztyn & 0.56 & 0.46 & $1969 / 70$ & $2019 / 20$ & Jelenia Góra & 0.26 & 0.36 & $1984 / 85$ & $1989 / 90$ \\
\hline Chojnice & 0.53 & 0.49 & $1969 / 70$ & $2019 / 20$ & Kielce & 0.39 & 0.39 & $1984 / 85$ & $2019 / 20$ \\
\hline Szczecin & 0.51 & $\underline{0.50}$ & $1969 / 70$ & $2019 / 20$ & Śnieżka & 0.22 & 0.26 & $1984 / 85$ & $1989 / 90$ \\
\hline Białystok & 0.59 & 0.47 & $1969 / 70$ & $2019 / 20$ & Sandomierz & 0.47 & 0.46 & $1984 / 85$ & $2019 / 20$ \\
\hline Mława & 0.57 & 0.47 & $1969 / 70$ & $2019 / 20$ & Opole & 0.26 & 0.40 & $1984 / 85$ & $1989 / 90$ \\
\hline Toruń & 0.46 & 0.47 & $1969 / 70$ & $2019 / 20$ & Kłodzko & 0.25 & 0.28 & $1984 / 85$ & $2006 / 07$ \\
\hline $\begin{array}{c}\text { Gorzów } \\
\text { Wielkopolski }\end{array}$ & 0.48 & 0.46 & $1969 / 70$ & $2019 / 20$ & Rzeszów & 0.54 & 0.40 & $1984 / 85$ & $2019 / 20$ \\
\hline Płock & 0.45 & 0.38 & $1969 / 70$ & $2019 / 20$ & Kraków & 0.35 & 0.44 & $1984 / 85$ & $2019 / 20$ \\
\hline Poznań & 0.49 & 0.43 & $1969 / 70$ & $2019 / 20$ & Racibórz & 0.29 & 0.24 & $1969 / 70$ & $2006 / 07$ \\
\hline Słubice & 0.49 & 0.41 & $1969 / 70$ & $2019 / 20$ & Tarnów & 0.38 & 0.45 & $1984 / 85$ & $2006 / 07$ \\
\hline Siedlce & 0.54 & 0.44 & $1969 / 70$ & $2019 / 20$ & Bielsko-Biała & 0.38 & 0.35 & $1984 / 85$ & $2013 / 14$ \\
\hline Warszawa & 0.52 & 0.48 & $1969 / 70$ & $2019 / 20$ & Lesko & 0.38 & 0.16 & $1984 / 85$ & $2013 / 14$ \\
\hline Terespol & 0.61 & 0.50 & $1984 / 85$ & $2019 / 20$ & Zakopane & 0.35 & 0.34 & $1984 / 85$ & $1989 / 90$ \\
\hline Zielona Góra & 0.38 & 0.39 & $1969 / 70$ & $2019 / 20$ & $\begin{array}{l}\text { Kasprowy } \\
\text { Wierch }\end{array}$ & 0.19 & 0.23 & $1984 / 85$ & $2019 / 20$ \\
\hline
\end{tabular}

bold $-p<0.05$, bold and underlined $-p<0.01$, bold and ${ }^{*}-p<0.001$.

The warmest winter in the analyzed multiannual period was recorded in season 2019/20. It broke a record in 31 out of 40 stations (Table 1). Mean Tmax for the season was $5.6{ }^{\circ} \mathrm{C}$ for the entire area. Except for mountain areas, the lowest mean Tmax was recorded in the north-east and east of the country, and highest in the south-west and west (Figure 2). In particular stations, mean Tmax values varied from $4.1^{\circ} \mathrm{C}$ in Suwałki to $7.8^{\circ} \mathrm{C}$ in Wrocław. Mean Tmax below $0{ }^{\circ} \mathrm{C}$ was only recorded in high mountain stations. It was $-1.3^{\circ} \mathrm{C}$ on Kasprowy Wierch and $-0.3^{\circ} \mathrm{C}$ on Śnieżka. Mean Tmax in the analyzed season was higher than average from the multiannual period from $3{ }^{\circ} \mathrm{C}$ in Lesko and Zakopane to $4.9^{\circ} \mathrm{C}$ in Suwałki.

Different thermal conditions developed in particular months of the winter season. In a large majority of stations, the lowest values of mean monthly Tmin were recorded in the first half of the analyzed period. The highest mean monthly Tmax was observed in seasons in the last two decades, and season 1989/90. In December, the lowest mean monthly Tmin in the majority of stations (in 33 out of 40 stations) occurred in winter 1969/70, and varied from $-13.8^{\circ} \mathrm{C}$ in Suwałki to $-5.7^{\circ} \mathrm{C}$ in Hel. The highest mean monthly Tmax for that month over the study area (in 34 out of 40 stations) was recorded in season 2015/16, with values from $4.7^{\circ} \mathrm{C}$ in Suwałki to $9.8^{\circ} \mathrm{C}$ in Wrocław. In mountain stations, thermal 
conditions developed at a level of $-0.9{ }^{\circ} \mathrm{C}$ on Kasprowy Wierch and $2.8^{\circ} \mathrm{C}$ on Śnieżka. In January, in as many as 39 stations, the lowest mean monthly Tmin was recorded in season $1986 / 87$, varying from $-20.4{ }^{\circ} \mathrm{C}$ in Białystok to $-9{ }^{\circ} \mathrm{C}$ in Świnoujście. Below $-20{ }^{\circ} \mathrm{C}$ was also recorded in other stations of eastern Poland, i.e., in Suwałki and Terespol. Except for mountain stations, the highest mean monthly Tmax was recorded in season 2006/07. Its value varied from $3.5^{\circ} \mathrm{C}$ in Suwałki to $8.1^{\circ} \mathrm{C}$ in Słubice. In the aforementioned mountain stations, thermal conditions fluctuated around $-2.6{ }^{\circ} \mathrm{C}$ on Kasprowy Wierch and $-2{ }^{\circ} \mathrm{C}$ on Śnieżka. In the last month of the winter season, i.e., in February, the lowest monthly Tmin in the majority of stations (in 30 out of 40 stations) was recorded in winter 1985/86. It varied from $-16.5{ }^{\circ} \mathrm{C}$ in Suwałki to $-8{ }^{\circ} \mathrm{C}$ in Hel. Moreover, in nine stations located in south-eastern Poland, the lowest mean monthly Tmin was recorded in winter 1984/85. The highest mean monthly Tmax primarily occurred in season 1989/90, and varied from $6.7^{\circ} \mathrm{C}$ in Suwałki to $11.5^{\circ} \mathrm{C}$ in Stubice. Lower values were observed in mountain stations, i.e., $-1.1^{\circ} \mathrm{C}$ on Kasprowy Wierch and $0.9^{\circ} \mathrm{C}$ on Śnieżka.
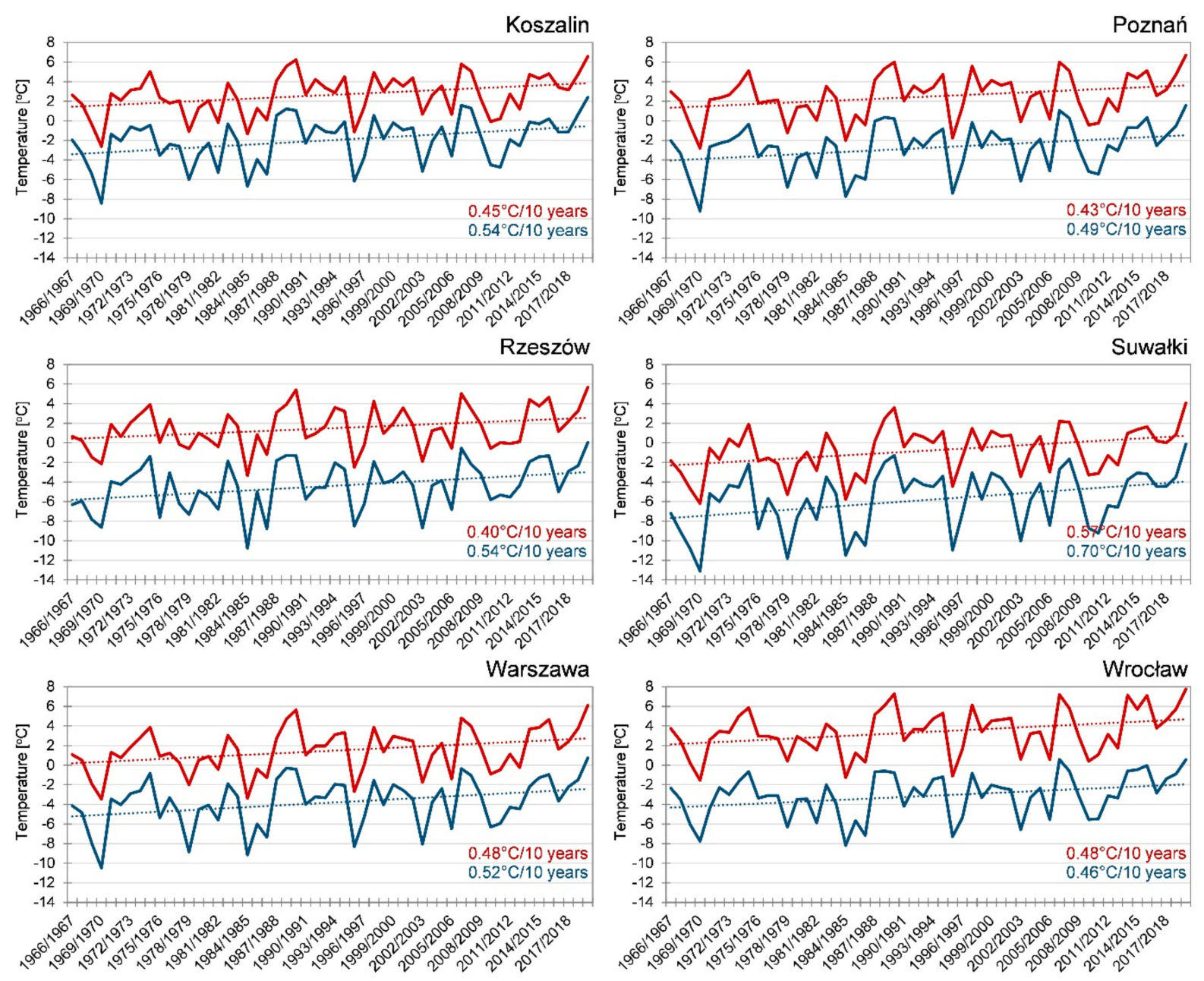

Figure 3. Course of mean Tmin (blue line) and Tmax (red line) in winter in the years 1966/67-2019/20 with rate of changes.

In the analyzed years, the lowest daily Tmin occurred mainly in January, and the highest daily Tmax in the second half of February or at the beginning of December. The lowest daily Tmin over the major area (particularly in the eastern and central regions of the country) was $\leq-30{ }^{\circ} \mathrm{C}$ (Figure 4 ). In particular stations, the absolute minimum Tmin varied from $-35.4{ }^{\circ} \mathrm{C}$ in Białystok to $-18.2^{\circ} \mathrm{C}$ in Hel. In the majority of stations, the values were recorded in season 1986/87 (particularly on 14.01 and 08.01) and 1984/85 (particularly on 8.01). The highest daily Tmax reached $>20{ }^{\circ} \mathrm{C}$ in Tarnów (20.6 $\left.{ }^{\circ} \mathrm{C} ; 25.02 .1990\right)$. In a 
large majority of stations, the highest values were recorded in winter season 1989/90. As evidenced above, in many stations that season was the warmest in the analyzed 54-year period. The above data suggest that the range of air temperature fluctuations in the winter season in Poland was $56^{\circ} \mathrm{C}$, and in particular stations it varied from $31.1^{\circ} \mathrm{C}$ in Hel to $52.3^{\circ} \mathrm{C}$ in Kielce. A decrease in the range of fluctuations occurred from the east to the west and north of the country.

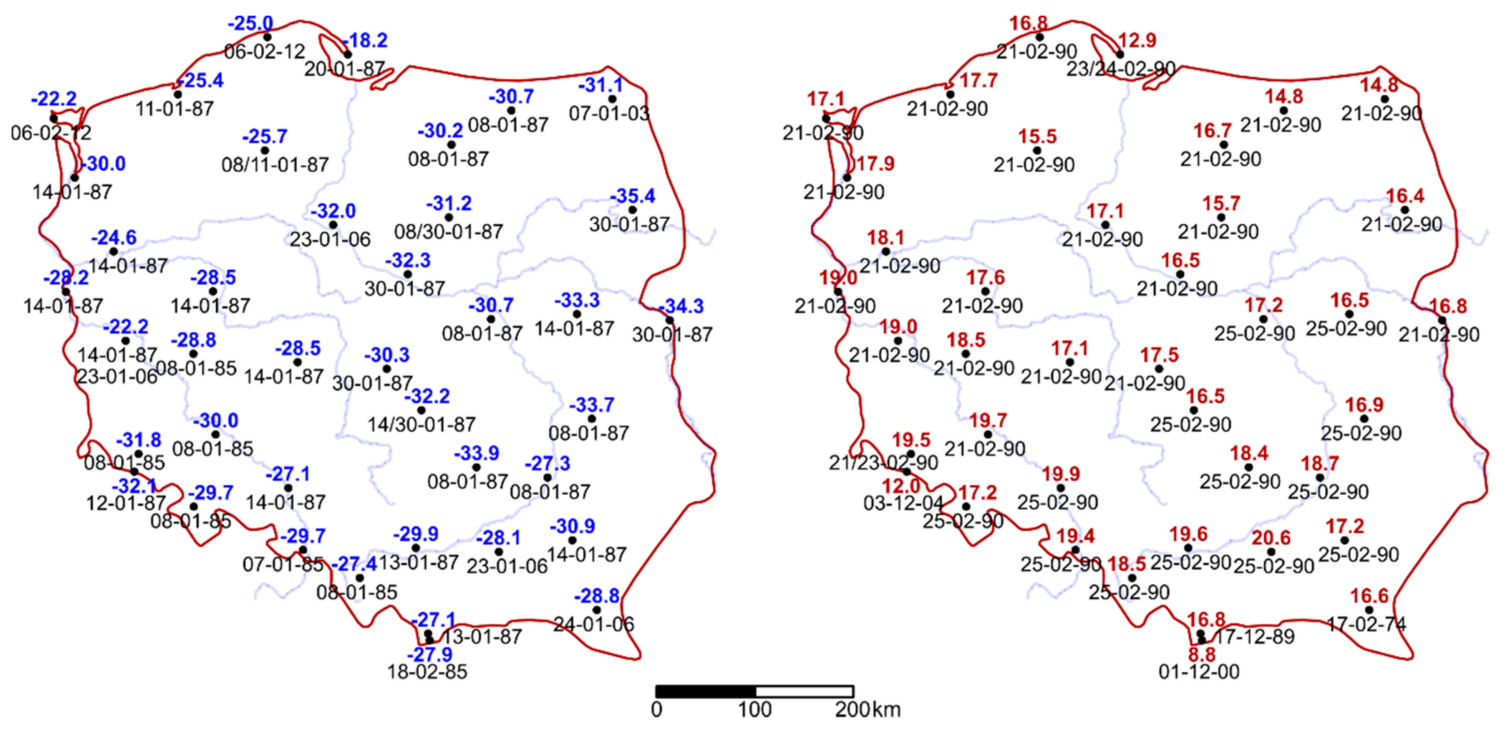

Figure 4. Lowest daily Tmin (left map) and highest daily Tmax (right map) in winter in the years 1966/67-2019/20.

\subsection{Snow Cover}

In Poland, the number of days with snow cover recorded during three winter months in the years 1966/67-2019/20 varied from 25 days in the north-west (Szczecin) to 62 days in the north-east (Suwałki) and 88-90 days in the mountains (Figure 5). In the Tatra Mountains (Kasprowy Wierch), scarce days with no snow cover were only recorded in the beginning of December. In the Sudetes (Śnieżka), days with no snow cover were more numerous, and occurred in December and in the beginning of January. In lowland areas, the western part of the country remained considerably less snowy (less than 40 days with snow cover) than the eastern part, where an average number of days with snow cover exceeded 50 . The permanence of snow cover largely depends on temperature, particularly the transition through $0{ }^{\circ} \mathrm{C}$. Therefore, maps of snow cover largely reflect the distribution of mean temperature of winter months.

A similar spatial distribution is characteristic of mean snow cover depth, and the lowest (below $6 \mathrm{~cm}$ ) mean values for three winter months were observed in the western part of Poland (Figure 6). In lowlands, snow cover reached the highest average long-term depth in the eastern frontiers $(>10 \mathrm{~cm})$, and more than $14 \mathrm{~cm}$ in Suwałki. These values are hardly impressive in comparison to mean snow cover thickness in the mountains, where an average of $72 \mathrm{~cm}$ (Śnieżka) and $93 \mathrm{~cm}$ is recorded (Kasprowy Wierch).

Like thermal conditions, the snowiness of winters are characterized by high variability and are subject to strong fluctuations from season to season (Figure 7). In the analyzed multiannual period, thermally extreme winters also proved extremely snowy, and in almost all stations (with the exception of Bielsko Biała), season 1969/70 was characterized by the highest number of days with snow cover. In this season, snow cover persisted throughout the winter in Poland resulting in positive anomalies of snow cover duration from 30 days in the east to more than 60 days in the west of Poland (Figure 5). Season 1969/70 also stood out in terms of snow cover depth. This parameter showed the highest deviations in the north-east, where snow cover was more than $25 \mathrm{~cm}$ thicker than on average (Figure 6). 
In the south of Poland (Kasprowy Wierch, Lesko, Śnieżka), in winter months of season 1969/70, considerably lower snow cover depth was recorded.
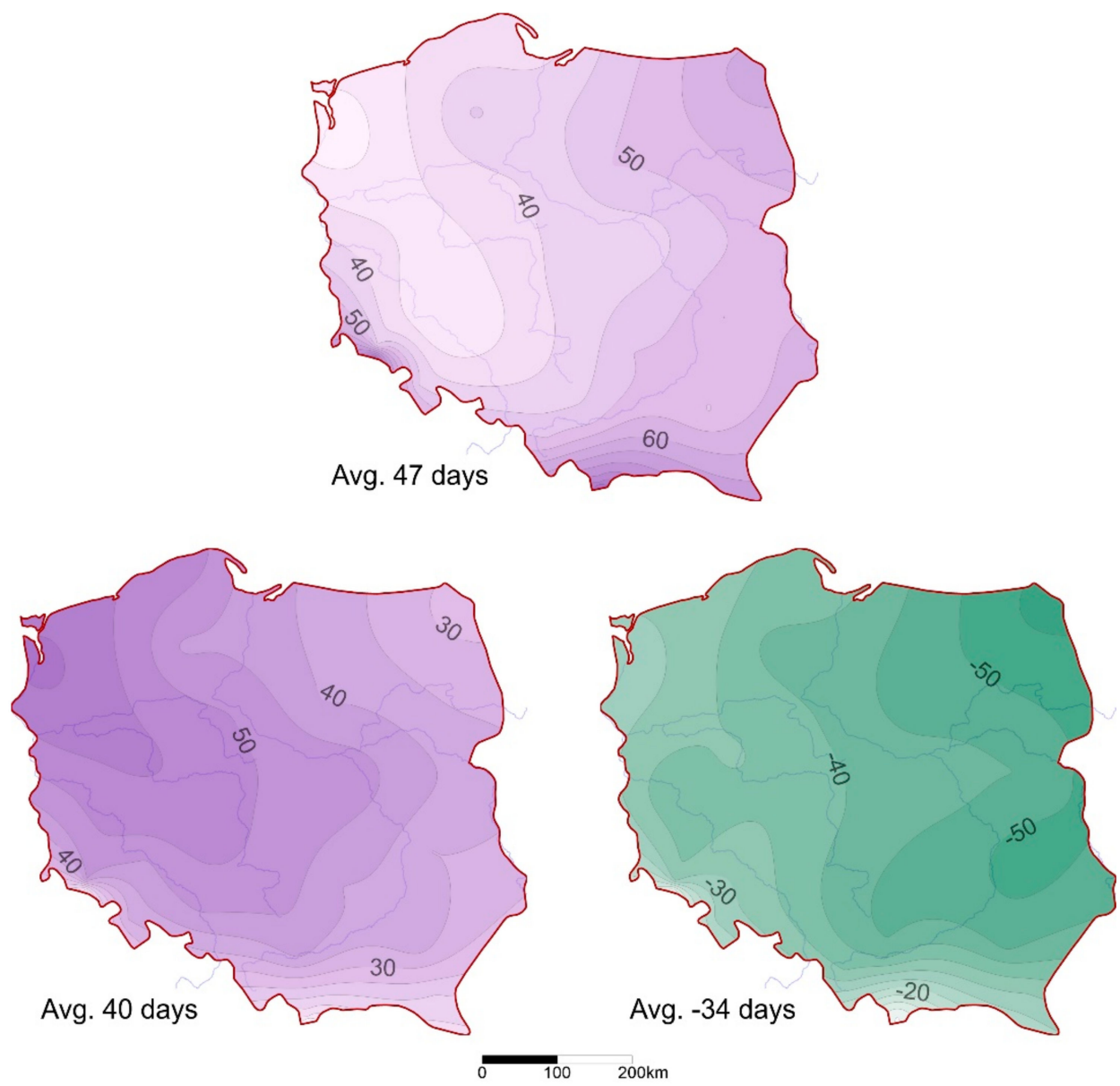

Figure 5. Mean winter number of days with snow cover averaged for winters 1966/1967-2019/2020 (top). Anomalies of number of days in extreme winters 1969/1970 (bottom left) and 2019/2010 (bottom right).

During the warmest winter, namely the last winter of the study period, i.e., 2019/20, at 14 stations, primarily in the west and center of Poland, snow cover did not occur at all, and in the east and in the mountains, snow cover persisting shorter than usual was considerably thinner than usual (Figure 6).

An increase in temperature in winter months in the moderately climate zone is related to the transition of temperature through the value of $0{ }^{\circ} \mathrm{C}$, considerably affecting the formation and permanence of snow cover. Due to a considerable increase in temperature in winters recorded in the analyzed period 1966/1967-2019/2020, in the majority of stations (19 out of 31), a statistically significant decrease in the number of days with snow cover was determined, progressing at a rate from 3.5 to 4.9 days /10 years (Table 2). In areas with the most abundant snow cover and lowest temperature, i.e., in the cold and snowy east of Poland and in the mountains and submontane areas, the trends were negative, but statistically non-significant. The trend proved positive only on Śnieżka (Sudetes), and was approximate to zero. Only in three stations: Suwałki and Siedlce in the north-east and Łeba in the north, a statistically significant decrease in the depth of snow cover was recorded. Over the remaining area, the trend was negative (with the exception of Kasprowy Wierch), but statistically non-significant. 

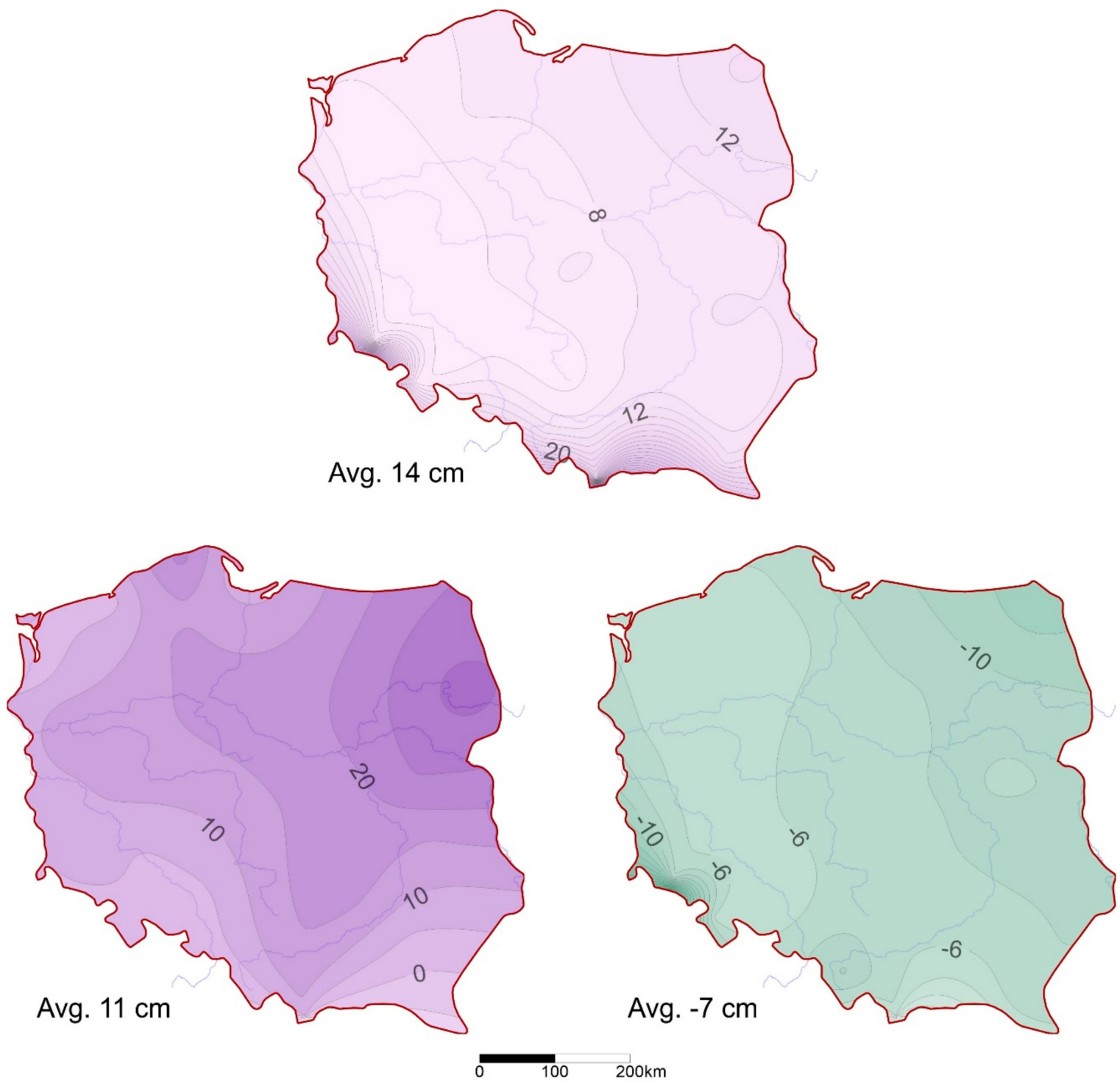

Figure 6. Mean snow cover depth averaged for winters 1966/1967-2019/2020 (top). Anomalies in mean snow cover depth in extreme winters 1969/1970 (bottom left) and 2019/2010 (bottom right).

\subsection{Effect of Circulation Conditions}

In the analyzed years, mean value of the $\mathrm{NAO}$ index in winter varied from -1.7 in season 2009/10 to 1.7 in season 2014/15. In the case of SCAND, its values varied from -1.1 in season 1988/89 to 1.6 in season 1971/72. The analyzed multiannual period showed an increase in the values of NAO index and a decrease in SCAND index. The recorded changes were statistically significant only in the case of NAO. During the coldest winter (1969/70), NAO index value was -0.38 , and SCAND index 0.53. During the warmest winter $(2019 / 20)$, the values of the analyzed indices were 1.27 and -0.80 , respectively.

The research in the analyzed area (except for the station on Kasprowy Wierch and in Lesko in the case of Tmin and SCAND, and in Lesko in the case of Tmax and SCAND) showed statistically significant correlations between thermal conditions in winter in Poland and selected teleconnection patterns, namely, NAO and SCAND. The effect of these circulation types showed spatial variability, and decreased from the north to the south of the country. In the case of $\mathrm{NAO}$, the correlation coefficient $r$ was positive, and ranged at a similar level both for Tmin (mean 0.62) and Tmax (mean 0.63). In the case of SCAND, correlation coefficient $r$ was negative, and stronger for Tmin (mean -0.44 ). 

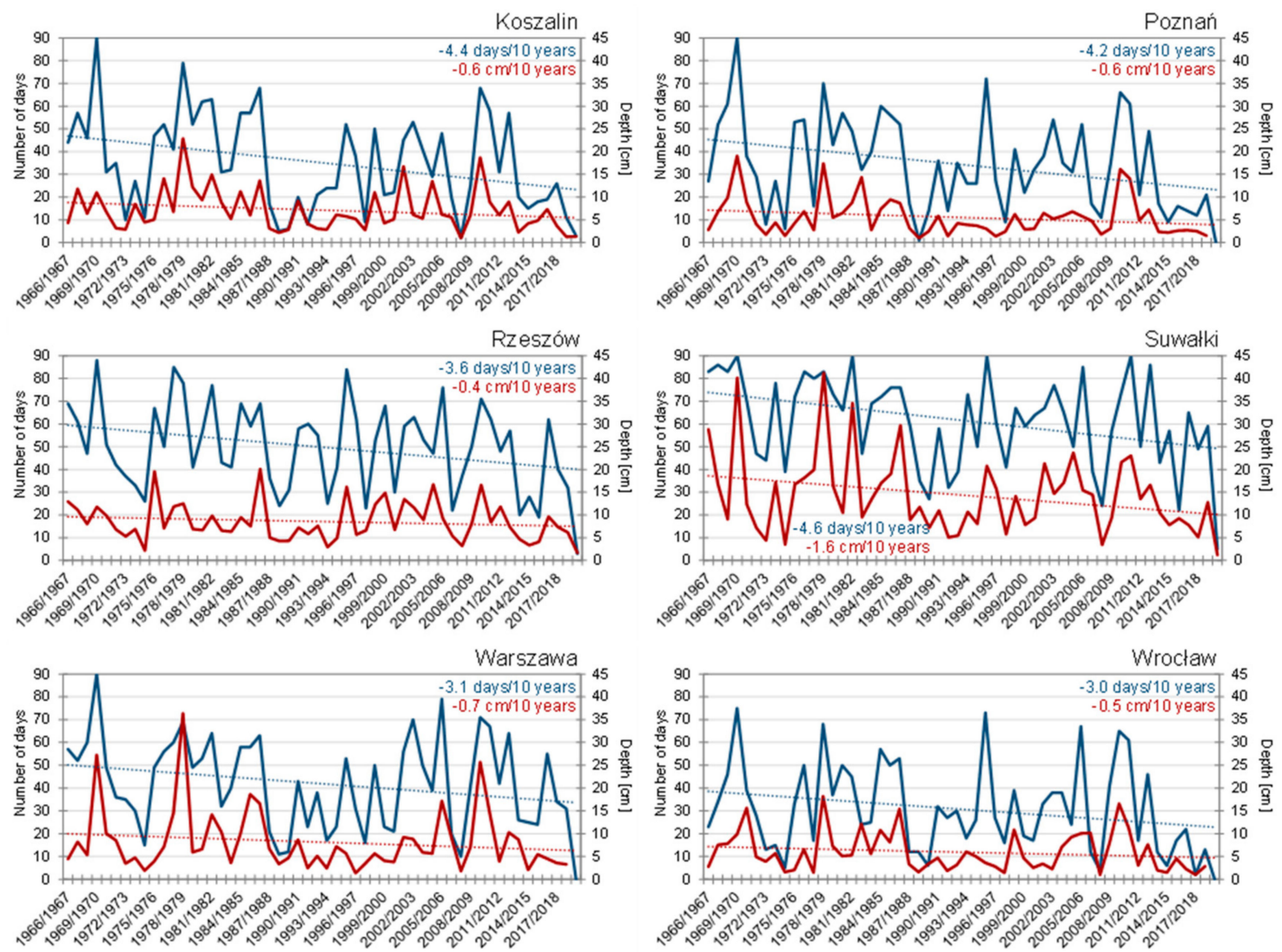

Figure 7. Course of the number of days with snow cover (blue) and mean thickness of snow cover (red) in winter in the years 1966/67-2019/20 with rate of changes.

Table 2. Variability of snow cover duration and mean depth for winter months in seasons 1966/67-2019/20. Stations are arranged in spatial order from the north to the south.

\begin{tabular}{|c|c|c|c|c|c|c|c|c|c|}
\hline Station & $\begin{array}{l}\text { Change } \\
\text { in } \\
\text { Duration } \\
\text { [days/10 } \\
\text { years] }\end{array}$ & $\begin{array}{c}\text { Change } \\
\text { in Depth } \\
\text { [cm/10 } \\
\text { years] }\end{array}$ & $\begin{array}{l}\text { Most } \\
\text { Snowy } \\
\text { Season }\end{array}$ & $\begin{array}{l}\text { Least } \\
\text { Snowy } \\
\text { Season }\end{array}$ & Station & $\begin{array}{l}\text { Change } \\
\text { in } \\
\text { Duration } \\
\text { [days/10 } \\
\text { years] }\end{array}$ & $\begin{array}{c}\text { Change } \\
\text { in Depth } \\
{[\mathrm{cm} / 10} \\
\text { years] }\end{array}$ & $\begin{array}{l}\text { Most } \\
\text { Snowy } \\
\text { Season }\end{array}$ & $\begin{array}{l}\text { Least } \\
\text { Snowy } \\
\text { Season }\end{array}$ \\
\hline Łeba & -3.9 & -1.4 & $1969 / 1970$ & $2019 / 2020$ & Kalisz & -4.9 & -0.7 & $1969 / 1970$ & $2019 / 2020$ \\
\hline Hel & -4.0 & -0.6 & $\begin{array}{l}1969 / 1970 \\
1981 / 1982\end{array}$ & $2019 / 2020$ & Łódź & -4.6 & -0.7 & $1969 / 1970$ & $2019 / 2020$ \\
\hline Koszalin & -4.4 & -0.6 & $1969 / 1970$ & $2007 / 2008$ & Lublin & -3.5 & -0.4 & $\begin{array}{l}1969 / 1970 \\
1981 / 1982\end{array}$ & $2019 / 2020$ \\
\hline Suwałki & -4.6 & -1.6 & $\underset{*}{4 \text { seasons }}$ & $2019 / 2020$ & Wrocław & -3.0 & -0.5 & $1969 / 1970$ & $2019 / 2020$ \\
\hline Świnoujście & -4.3 & -0.4 & $1969 / 1970$ & $2019 / 2020$ & $\begin{array}{c}\text { Jelenia } \\
\text { Góra }\end{array}$ & -1.8 & -0.3 & $1969 / 1970$ & $2006 / 2007$ \\
\hline Chojnice & -4.6 & -1.0 & $1969 / 1970$ & $2019 / 2020$ & Kielce & -4.2 & -0.5 & $1969 / 1970$ & $2019 / 2020$ \\
\hline Szczecin & -4.2 & -0.5 & $1969 / 1970$ & $\begin{array}{l}1988 / 1989 \\
2019 / 2020\end{array}$ & Śnieżka & 0.0 & -0.7 & $\begin{array}{c}37 \\
\text { seasons * }\end{array}$ & $1967 / 1968$ \\
\hline Białystok & -4.2 & -1.4 & $1969 / 1970$ & $2019 / 2020$ & Opole & -2.8 & -0.2 & $1969 / 1970$ & $2019 / 2020$ \\
\hline Mława & -3.2 & -0.2 & $1969 / 1970$ & $2019 / 2020$ & Kłodzko & -1.7 & -0.2 & $1969 / 1970$ & $2013 / 2014$ \\
\hline
\end{tabular}


Table 2. Cont.

\begin{tabular}{|c|c|c|c|c|c|c|c|c|c|}
\hline Station & $\begin{array}{l}\text { Change } \\
\text { in } \\
\text { Duration } \\
\text { [days } / 10 \\
\text { years] }\end{array}$ & $\begin{array}{c}\text { Change } \\
\text { in Depth } \\
\text { [cm/10 } \\
\text { years] }\end{array}$ & $\begin{array}{l}\text { Most } \\
\text { Snowy } \\
\text { Season }\end{array}$ & $\begin{array}{l}\text { Least } \\
\text { Snowy } \\
\text { Season }\end{array}$ & Station & $\begin{array}{l}\text { Change } \\
\text { in } \\
\text { Duration } \\
\text { [days/10 } \\
\text { years] }\end{array}$ & $\begin{array}{c}\text { Change } \\
\text { in Depth } \\
\text { [cm/10 } \\
\text { years] }\end{array}$ & $\begin{array}{l}\text { Most } \\
\text { Snowy } \\
\text { Season }\end{array}$ & $\begin{array}{c}\text { Least } \\
\text { Snowy } \\
\text { Season }\end{array}$ \\
\hline Toruń & -4.1 & -0.3 & & $2019 / 2020$ & Rzeszów & -3.6 & -0.4 & $1969 / 1970$ & $2019 / 2020$ \\
\hline $\begin{array}{l}\text { Gorzów } \\
\text { Wielkopol- } \\
\text { ski }\end{array}$ & -4.1 & -0.5 & $1969 / 1970$ & $2019 / 2020$ & Kraków & -3.5 & & $\begin{array}{l}\text { 1969/1970 } \\
1995 / 1006\end{array}$ & $2019 / 2020$ \\
\hline Poznań & -4.2 & -0.6 & $1969 / 1970$ & $2019 / 2020$ & $\begin{array}{c}\text { Bielsko- } \\
\text { Biała }\end{array}$ & -3.5 & -0.1 & $2005 / 2006$ & $2013 / 2014$ \\
\hline Siedlce & -3.1 & -1.5 & $1969 / 1970$ & $2019 / 2020$ & Lesko & -1.3 & & $1966 / 1967$ & $2006 / 2007$ \\
\hline Warszawa & -3.1 & -0.7 & $1969 / 1970$ & $2019 / 2020$ & Zakopane & -1.6 & -0.8 & $\begin{array}{c}10 \\
\text { seasons * }\end{array}$ & $2015 / 2016$ \\
\hline Terespol & $-2,9$ & -0.8 & $1969 / 1970$ & $2019 / 2020$ & $\begin{array}{c}\text { Kasprowy } \\
\text { Wierch }\end{array}$ & -0.1 & 0.1 & $\begin{array}{c}49 \\
\text { seasons * }\end{array}$ & $2000 / 2001$ \\
\hline $\begin{array}{c}\text { Zielona } \\
\text { Góra }\end{array}$ & -4.0 & -0.4 & $1969 / 1970$ & $2019 / 2020$ & & & & & \\
\hline
\end{tabular}

bold $-p<0.05$; bold and underlined $-p<0.01 ;{ }^{*}$ more than one season (including 1969/1970).

In the negative NAO phase, Tmin and Tmax were lower than in the positive phase (Figure 8). The greatest differences were recorded in north-eastern Poland, and decreased southwards. In particular stations, the differences varied from $1.2{ }^{\circ} \mathrm{C}$ for Tmin and $1.6^{\circ} \mathrm{C}$ for Tmax on Kasprowy Wierch to $5^{\circ} \mathrm{C}$ for Tmin and $4{ }^{\circ} \mathrm{C}$ for Tmax w Suwałki. Differences in Tmin and Tmax in the positive and negative NAO phase were statistically significant, in more than $92 \%$ of stations at a level of 0.001 .

Similarly in the case of SCAND, different thermal conditions were recorded in the negative and positive phase of the pattern. In the negative phase, higher Tmin and Tmax was recorded than in the positive phase (Figure 8). Like in the case of NAO, the differences decreased from the north-east towards the south of the country, and varied from $0.2{ }^{\circ} \mathrm{C}$ on Kasprowy Wierch to $3.3{ }^{\circ} \mathrm{C}$ in Białystok for Tmin and from $0.9{ }^{\circ} \mathrm{C}$ on Kasprowy Wierch to $3.1^{\circ} \mathrm{C}$ in Białystok, Kętrzyn, Mława, Terespol, and Torun for Tmax. Apart from four stations (Kasprowy Wierch, Lesko, Śnieżka, Zakopane), in the case of Tmin and three stations (Kasprowy Wierch, Lesko, Śnieżka) for Tmax, differences in air temperature between SCAND phases were statistically significant. A higher level of statistical significance was determined for Tmax.

A strong dependency on the pressure field over the Euro-Atlantic sector and on the direction of advection of air masses is characteristic for snow cover duration. The correlation of the number of days with snow cover during three winter months and indices of two teleconnection patterns over the majority of the territory of Poland is statistically significant (Figure 9). The correlation with NAO index is negative, and equals $<-0.6$, with the exception of mountain and submontane stations (Śnieżka, Kasprowy Wierch, and Zakopane), where the correlation coefficient $r$ was approximate to zero and statistically non-significant. Such a dependency translates into the occurrence of statistically significant at a level of 0.001 (with the exception of mountain stations) differences in the duration of snow cover in the positive and negative NAO phase. In the negative phase which-as evidenced-favors temperature decrease, over 30 more days with snow cover are recorded than in the positive phase, both in the east of Poland and in the less snowy west. The effect of NAO considerably weakens in submontane regions, where the difference in snow cover duration in the positive and negative phase does not exceed 15 days. 

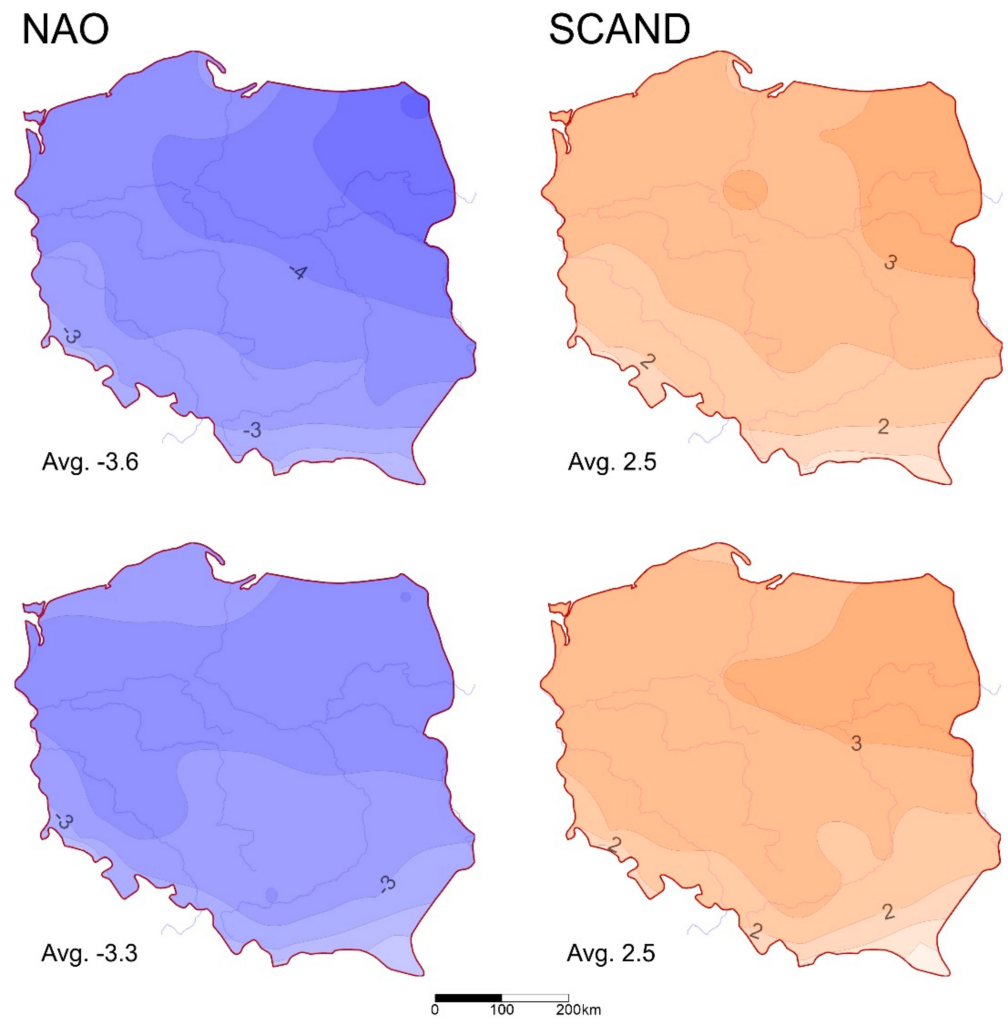

Figure 8. Difference in Tmin (top maps) and Tmax (bottom maps) between the negative and positive phase of teleconnection patterns.
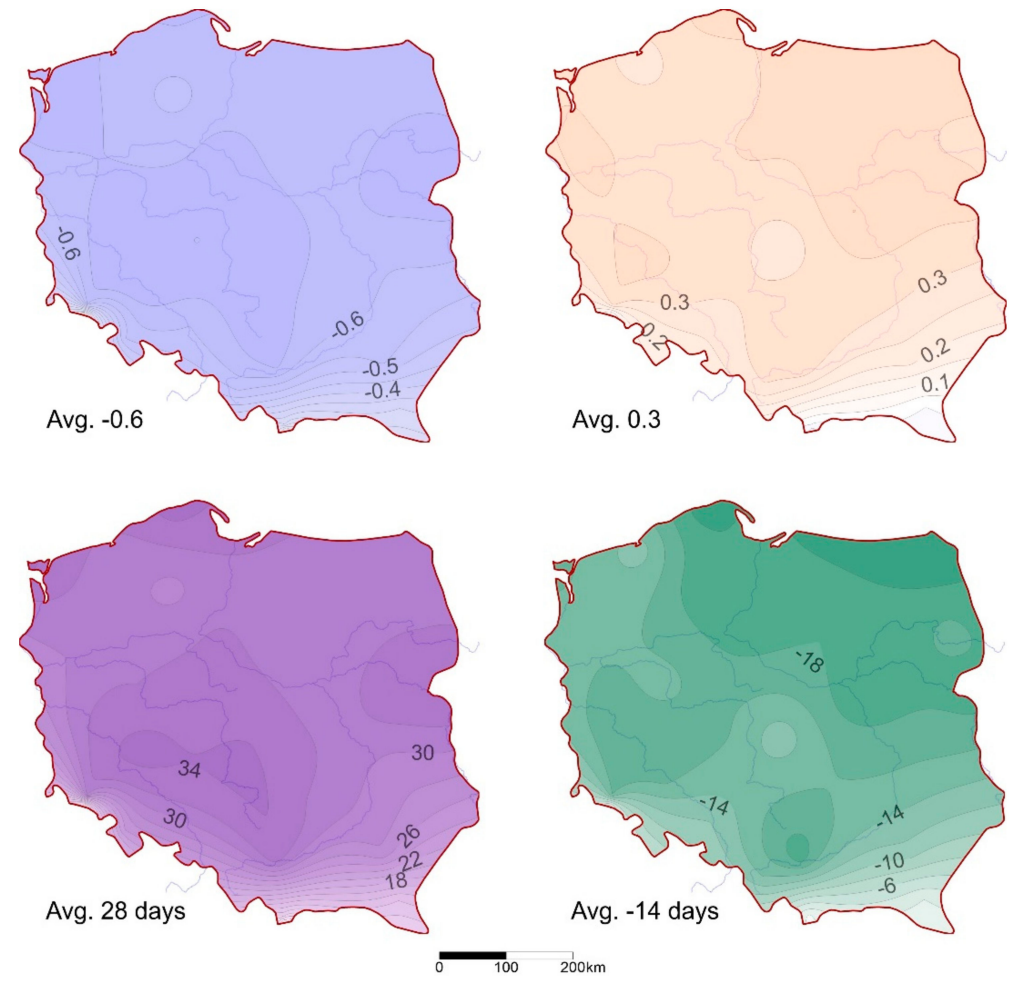

Figure 9. Correlation between the number of days with snow cover and North Atlantic Oscillation (NAO)/ Scandinavian pattern (SCAND) winter indices (upper row), and difference in snow cover duration between the negative and positive phase of NAO/SCAND (lower row). 
The SCAND pattern has a weaker effect on the snowiness of winters in Poland, and the correlation coefficient $r$ of the SCAND index with the number of days with snow cover in lowland areas is $0.3-0.35$ (Figure 9). The coefficient $r$ is lower and statistically nonsignificant in mountain and submontane stations, where it decreased to values approximate to zero. In the positive SCAND phase, a higher number of days with snow cover is therefore observed, particularly in the north-east, where snow is recorded 21 days longer than in the negative phase. In western and central Poland, snow persists more than two weeks longer in the positive SCAND phase. Differences in the duration of snow cover are statistically significant in more than $56 \%$ of stations at a level of 0.05 . Like in the case of NAO, the smallest difference in the duration of snow cover between the positive and negative SCAND phase is recorded in the south, where it only persists for several days.

\section{Discussion and Summary}

The study showed an increase in both Tmin and Tmax in winter. It was statistically significant over a majority of the country. The greatest changes were recorded in northeastern and northern regions. The obtained results confirm earlier studies conducted throughout the country [11] as well as in selected regions $[52,62,63]$. In the majority of stations, the recorded changes in Tmin were more considerable than changes in Tmax, particularly in the east of the country. A more intensive increase in Tmin in comparison to Tmax has also been pointed to by other authors, e.g., [11,64-67]. Forecasted changes in Tmin are generally more coherent in all models than for Tmax [65]. The authors explain it with the fact that changes in Tmin are weakly correlated with changes in cloudiness. A consequence of the progressing increase in air temperature is a decrease in the frequency of cold waves $[16,68]$ with a simultaneous increase in the frequency of warm waves in winter [15]. Another effect of the observed warming is a delay of the beginning and earlier end of thermal winter, and consequently a reduction of its duration $[69,70]$.

The coldest winters were recorded in the first half of the analyzed multiannual period. Exceptionally cold winters deserve particular attention, i.e., 1969/70 and 1984/85. As found earlier [71], it was also a period with frequently occurring cold waves. One of the most intensive cold waves occurred in 1987 [71,72], i.e., outside of the two coldest seasons. During that wave, in many stations of central Europe, the lowest Tmax of cold waves to date was recorded [68]. The warmest winters occurred in the second half of the analyzed period. Among seasons with the highest mean Tmax, particularly winters 2019/20 and 1989/90 stood out. Analysis of the long-term research from Poznań [63] and Torun [62] reaffirms that season 2019/20 was the warmest at least since the second half of the 19th century. During the second of the aforementioned seasons, in the majority of stations, absolute maximums of Tmax were recorded not only in Poland, but also in other regions of central Europe [15]. The most important negative effect of occurrence of warm winters is a reduction of the duration and thickness of snow cover [18].

The increasing temperature of winter months in Poland is associated with significant changes in the occurrence of snow cover. In addition to its seasonal and multiannual variability, significant decreasing trends in snow cover duration have been found in the majority of stations in Poland, which confirm earlier results [35,37,38,73]. However, the trends in snow cover duration computed for the contemporary period (until 2019/2020) are stronger than the for the older periods (until 1998 [35] and until 2013 [38]), when a negative trend of snow cover duration was statistically significant at only a few stations [38] or even not significant at all with exception of mountain stations [35]. A further progression of the negative change in snow cover occurrence in Poland is projected for both the near (2021-2050) and far (2071-2100) future [39]. Trends in the snow cover duration in Poland are congruous to tendencies recognized over the entire Northern Hemisphere, where the duration of the snow season has declined by five days per decade since the early 1970s [31]. It should be emphasized that since the 1980s the rate of changes increased in Poland, as well as in many other regions of Europe, while the greatest changes have been observed in the Arctic [74]. 
Less significant negative trends were obtained for the changes in the depth of snow cover depth in Poland, which was reaffirmed in the previous studies [35,37,38]. While snow cover duration is strongly related to temperature, the amount of snow translating to the depth of the snow layer is reliant to the amount of precipitation coming in the form of snowfall. This explains the different rate of changes in snow cover depth and duration, which is particularly apparent in higher latitudes, as documented for Northern Eurasia [22]. Fontrodona Bach et al. [25] found decreases in maximum and mean snow depth over Europe, except in the coldest climates, however, mean snow depth generally decreases stronger than maximum seasonal snow depth.

In general, a decrease in snow cover depth was determined at lower, and an increase at higher altitudes in southern Poland. The same relationship was found in Norway [75]. In the case of stations at high altitudes, lack or only slight changes in snow depth in midwinter were recorded in the Swiss Alps, and negative tendencies were more evident in the case of stations at medium and low altitudes [76-78]. The same pattern was determined in the Romanian Carpathians [79] and Russia [80]. Some signals of a decrease in annual maximum snow depth in high altitudes were recorded in Swiss Alps [81].

The study showed a strong correlation of winter temperature and snow conditions with atmospheric circulation. This confirms earlier studies pointing to the main role of atmospheric circulation in shaping weather and climatic conditions at moderate latitudes $[82,83]$. Over a major study area, statistically significant correlations were determined between air temperature in winter and selected teleconnection patterns. The strength of the correlations decreased from the north to the south of the country. Among the selected circulation types, the North Atlantic Oscillation affected the thermal conditions the strongest. Among four circulation types affecting the weather and climate of central Europe [84], NAO and SCAND have the strongest effect in Poland $[51,52,85]$. In the negative NAO phase and positive SCAND phase, lower temperature was recorded in comparison to the positive and negative phase, respectively, and differences in air temperature over the major area were statistically significant. The occurrence of the negative NAO phase or positive SCAND phase is also related to longer duration of ice cover on lakes $[57,86]$. Deviations from the mean value in the case of NAO reach $>30$ days, and in the case of SCAND $>20$ days. The correlations of different conditions of warm Europe/cold Arctic, increasingly stronger since 1998, are also important. It was found earlier [87] that a decrease in temperature in winter in Europe is related to the negative NAO phase and positive SCAND phase, and higher temperature in the period is determined by opposite phases of these circulation types.

The study showed that, just like for temperature, NAO has a stronger effect on the snowiness of winters in Poland than SCAND. The effect of both circulation patterns shows spatial variability in Poland, confirming results obtained in other European regions for the Swiss Alps [78] or for Germany [88]. In the Romanian Carpathians, negative and weak correlations between the number of days with snow cover, particularly in the period from December to March, and seasonal values of the NAO index were determined [79]. High accumulation of snow during the occurrence of NAO was also found in Bulgaria [89]. In Poland the positive NAO phase is related to less snowy winters, and the negative phase to an increase in the probability of occurrence of a more snowy winter, and the difference in the number of days with snow cover in the positive and negative phase exceeds 30 days in the majority of stations, with the correlation coefficient amounting to $<-0.6$. A strong negative correlation between NAO and the number of days with snow cover in Poland was determined earlier, e.g., $[38,48,50]$. Snow cover in Poland is additionally correlated with NAO in October before the winter season [50]. This study showed that the SCAND pattern has a weaker effect on the snowiness of winters in Poland than NAO. Due to lower temperature, the positive SCAND phase causes a higher number of days with snow cover in Poland in comparison to the negative phase and the difference in the number of days in positive and negative phase amounts to a dozen or so, hardly exceeding 20 days in the northeast. However, it is different in other regions of Europe and years with low snow accumulation in Bulgaria [89] are related to the positive SCAND phase, because it caused 
warming in autumn, a delay of the beginning of the snow cover season, and a decrease in winter precipitation.

In Poland, both Tmin and Tmax increased in the winter period, although changes in Tmin were more considerable. Significant temperature changes are associated with declining snow cover, and extremely warm winters occurring most frequently in recent years proved to be also least snowy. This complies with global warming trends, which is most pronounced in the Northern Hemisphere terrestrial regions. However, winter weather conditions are also strongly influenced by the macroscale circulation, which is responsible for a great in-seasonal and multiannual variability of thermal conditions and snowiness and may partly disrupt the monotony of the contemporary warming trend.

Author Contributions: Conceptualization, A.M.T.; methodology, A.M.T. and E.B.; formal analysis, A.M.T. and E.B.; investigation, A.M.T. and E.B.; writing-original draft preparation, A.M.T., E.B. and K.S.-P.; writing-review and editing, A.M.T., E.B. and K.S.-P.; visualization, A.M.T. and E.B. All authors have read and agreed to the published version of the manuscript.

Funding: This research received no external funding.

Institutional Review Board Statement: Not applicable.

Informed Consent Statement: Not applicable.

Data Availability Statement: The data presented in this study are openly available at https:/ dane. imgw.pl/data/dane_pomiarowo_obserwacyjne/ and at https://www.cpc.ncep.noaa.gov/data/ teledoc/telecontents.shtml.

Conflicts of Interest: The authors declare no conflict of interest.

\section{References}

1. IPCC. Climate Change: The Physical Science Basis. Contribution of Working Group I to the Fifth Assessment Report of the Intergovernmental Panel in Climate Change; Cambridge University Press: Cambridge, UK, 2013.

2. Masson-Delmotte, V.; Zhai, H.-O.P.; Pörtner, D.; Roberts, J.; Skea, P.R.; Shukla, A.; Pirani, W.; Moufouma-Okia, C.; Péan, R.; Pidcock, S.; et al. (Eds.) Global Warming of $1.5^{\circ} \mathrm{C}$. An IPCC Special Report on the Impacts of Global Warming of $1.5^{\circ} \mathrm{C}$ Above PreIndustrial Levels and Related Global Greenhouse Gas Emission Pathways, in the Context of Strengthening the Global Response to the Threat of Climate Change, Sustainable Development, and Efforts to Eradicate Poverty; Cambridge University Press: Cambridge, UK, 2018.

3. Solomon, S.; Qin, M.D.; Manning, Z.; Chen, M.; Marquis, K.B.; Averyt, M.T.; Miller, H.L. (Eds.) Climate Change 2007: The Physical Science Basis. Contribution of Working Group I to the Fourth Assessment Report of the Intergovernmental Panel on Climate Change; Cambridge University Press: Cambridge, UK, 2007.

4. Piniewski, M.; Mezghani, A.; Szcześniak, M.; Kundzewicz, Z.W. Regional projections of temperature and precipitation changes: Robustness and uncertainty aspects. Meteorol. Z. 2017, 26, 223-234. [CrossRef]

5. Kjellström, E. Recent and future signatures of climate change in Europe. Ambio 2004, 33, 193-198. [CrossRef] [PubMed]

6. The Copernicus Climate Change Service (C3S). Available online: https:/ / climate.copernicus.eu/boreal-winter-season-1920-wasfar-warmest-winter-season-ever-recorded-europe-0 (accessed on 4 April 2020).

7. Lorenz, R.; Stalhandske, Z.; Fischer, E.M. Detection of a climate change signal in extreme heat, heat stress, and cold in Europe from observations. Geophys. Res. Lett. 2019, 46, 8363-8374. [CrossRef]

8. Bielec-Bakowska, Z.; Piotrowicz, K. Temperatury ekstremalne w Polsce w latach 1951-2006. Pr. Geogr. 2013, 132, 59-98.

9. Michalska, B. Tendencje zmian temperatury powietrza w Polsce. Pr. Studia Geogr. 2011, 47, 67-75.

10. Wójcik, R.; Miętus, M. Niektóre cechy wieloletniej zmienności temperatury powietrza w Polsce (1951-2010). Przegląd Geogr. 2014, 86, 339-364. [CrossRef]

11. Owczarek, M.; Filipiak, J. Contemporary changes of thermal conditions in Poland, 1951-2015. Bull. Geogr. Phys. Geogr. Ser. 2016, 10, 31-50. [CrossRef]

12. Matuszko, D.; Piotrowicz, K. Ekstremalne zdarzenia pogodowe w Krakowie i ich uwarunkowania cyrkulacyjne. In Rola Cyrkulacji Atmosfery w Kształtowaniu Klimatu; Bielec-Bakowska, Z., Łupikasza, E., Widawski, A., Eds.; Katedra Klimatologii, Wydział Nauk o Ziemi, Uniwersytet Ślaski: Sosnowiec, Poland, 2012; pp. 211-218.

13. Lhotka, O.; Kyselý, J. Characterizing joint effects of spatial extent, temperature magnitude and duration of heat waves and cold spells over Central Europe. Int. J. Climatol. 2015, 35, 1232-1244. [CrossRef]

14. Migała, K.; Urban, G.; Tomczyński, K. Long-term air temperature variation in the Karkonosze mountains according to atmospheric circulation. Theor. Appl. Climatol. 2016, 125, 337-351. [CrossRef]

15. Tomczyk, A.M.; Bednorz, E.; Sulikowska, A. Cold spells in Poland and Germany and their circulation conditions. Int. J. Climatol. 2019, 39, 4002-4014. [CrossRef] 
16. Van Oldenborgh, G.; Mitchell-Larson, E.; Vecchi, G.A.; de Vries, H.; Vautard, R.; Otto, F. Cold waves are getting milder in the northern midlatitudes. Environ. Res. Lett. 2019, 14, 114004. [CrossRef]

17. Koenigk, T.; Caian, M.; Nikulin, G.; Schimanke, S. Regional Arctic Sea ice variations as predictor for winter climate conditions. Clim. Dyn. 2016, 46, 317-337. [CrossRef]

18. Ziernicka-Wojtaszek, A.; Zuśka, Z. Zimy z dodatnią temperatura powietrza na obszarze Polski (1981-2010). Infrastrukt. Ekol. Teren. Wiej. 2016, 3, 983-993.

19. Feng, S.; Hu, Q. Changes in winter snowfall/precipitation ratio in the contiguous United States. J. Geophys. Res. Atmos. 2007, 112, D15. [CrossRef]

20. Dong, C.; Menzel, L. Recent snow cover changes over central European low mountain ranges. Hydrol. Process. 2019, $24,321-338$. [CrossRef]

21. Brown, R.D.; Robinson, D.A. Northern Hemisphere spring snow cover variability and change over $1922-2010$ including an assessment of uncertainty. Cryosphere 2011, 5, 219-229. [CrossRef]

22. Bulygina, O.N.; Razuvaev, V.N.; Korshunova, N.N. Changes in snow cover over Northern Eurasia in the last decades. Environ. Res. Lett. 2009, 4, 045026. [CrossRef]

23. Henderson, G.R.; Leathers, D.J. European snow cover extent variability and associations with atmospheric forcings. Int. J. Climatol. 2010, 30, 1440-1451. [CrossRef]

24. Ye, K.; Lau, N.C. Influences of surface air temperature and atmospheric circulation on winter snow cover variability over Europe. Int. J. Climatol. 2017, 37, 2606-2619. [CrossRef]

25. Fontrodona Bach, A.; van der Schrier, G.; Melsen, L.A.; Klein Tank, A.M.G.; Teuling, A.J. Widespread and accelerated decrease of observed mean and extreme snow depth over Europe. Geophys. Res. Lett. 2018, 45, 312-319. [CrossRef]

26. Armstrong, R.L.; Brun, E. (Eds.) Snow and Climate: Physical Processes, Surface Energy Exchange and Modeling; Cambridge University Press: Cambridge, UK, 2008; p. 256. ISBN 10 0-521854-54-7.

27. Kjellström, E. Changes in the probability distribution functions for temperature between an A2 scenario run and a control run with RCA)-H. SWECLIM Newsl. 2003, 14, 12-16.

28. Räisänen, J.; Hansson, U.; Ullerstig, A.; Döscher, R.; Graham, L.P.; Jones, C.; Meier, M.; Samuelsson, P.; Willen, U. GCM driven simulations of recent and future climate with the Rossby Centre coupled atmosphere Baltic Sea regional climate model. $R C A O$ Rep. Meteorol. Climatol. 2003, 101, 1-61.

29. Van den Besselaar, E.J.M.; Klein Tank, A.M.G.; van der Schrier, G. Influence of circulation types on temperature extremes in Europe. Theor. Appl. Climatol. 2010, 99, 431-439. [CrossRef]

30. Brown, R.D. Northern Hemisphere snow cover variability and change, 1915-1997. J. Clim. 2000, 13, 2339-2355. [CrossRef]

31. Choi, G.; Robinson, D.A.; Kang, S. Changing Northern Hemisphere snow seasons. J. Clim. 2010, 23, 5305-5310. [CrossRef]

32. Falarz, M. Long-term variability in reconstructed and observed snow cover over the last 100 winter seasons in Cracow and Zakopane (southern Poland). Clim. Res. 2002, 19, 247-256. [CrossRef]

33. Hyvärinen, V. Trends and characteristics of hydrological time series in Finland. Nord. Hydrol. 2003, 34, 71-90. [CrossRef]

34. Kohler, J.; Brandt, O.; Johansson, M.; Callaghan, T.V. A long-term Arctic snow depth record from Abisko, northern Sweden, 1913-2004. Polar Res. 2006, 25, 91-113. [CrossRef]

35. Falarz, M. Variability and trends in the duration and depth of snow cover in Poland in the 20th Century. Int. J. Climatol. 2004, 24, 1713-1727. [CrossRef]

36. Falarz, M. Changes of extreme nival conditions in Poland during the second half of the 20th century. Meteorol. Z. 2008, 17, 339-444. [CrossRef]

37. Czarnecka, M. Częstość występowania i grubość pokrywy śnieżnej w Polsce. Acta Agroph. 2012, 19, 501-514.

38. Szwed, M.; Pińskwar, I.; Kundzewicz, Z.W.; Graczyk, D.; Mezghani, A. Changes of snow cover in Poland. Acta Geophys. 2017, 65, 65-76. [CrossRef]

39. Szwed, M.; Dobler, A.; Mezghani, A.; Saloranta, T.M. Change of maximum snow cover depth in Poland-Trends and projections. Idojaras 2019, 123, 487-500. [CrossRef]

40. Jaagus, J. The impact of climate change on the snow cover pattern in Estonia. Clim. Chang. 1997, 36, 65-77. [CrossRef]

41. Niedźwiecki, M. Charakterystyka pokrywy śnieżnej w Łodzi w latach 1950-1989. Acta Univ. Lodz. Folia Geograph. Phys. 1998, 3, 265-277.

42. Adaptation in Europe; Report No. 3; European Environment Agency: Copenhagen, Denmark, 2013.

43. Climate Change, Impacts and Vulnerability in Europe 2012-An Indicator-Based Report; Report No. 12; European Environment Agency: Copenhagen, Denmark, 2012.

44. Mezghani, A.; Parding, K.M.; Dobler, A.; Benestad, R.E.; Haugen, J.E.; Piniewski, M. Projekcje zmian temperatury, opadów i pokrywy śnieżnej. In Zmiany Klimatu i Ich Wptyw na Wybrane Sektory w Polsce; Kundzewicz, Z., Hov, Ø., Okruszko, T., Eds.; ISRL PAN Poznań: Poznań, Poland, 2017.

45. Piotrowski, P.; Jędruszkiewicz, J. Projections of thermal conditions for Poland for winters 2012-2050 in relations to atmospheric circulation. Meteorol. Z. 2013, 22, 569-575. [CrossRef]

46. Brown, I. Snow cover duration and extent for Great Britain in a changing climate: Altitudinal variations and synoptic scale influences. Int. J. Climatol. 2019, 39, 4611-4626. [CrossRef] 
47. Clark, M.P.; Serreze, M.C.; Robinson, D.A. Atmospheric controls on Eurasian snow extent. Int. J. Climatol. 1999, 19, 27-40. [CrossRef]

48. Bednorz, E. Snow cover in western Poland and macro-scale circulation conditions. Int. J. Climatol. 2002, 22, 533-541. [CrossRef]

49. Bednorz, E. Snow cover in eastern Europe in relation to temperature, precipitation and circulation. Int. J. Climatol. 2004, 24, 591-601. [CrossRef]

50. Falarz, M. Snow cover variability in Poland in relation to the macro- and mesoscale atmospheric circulation in the 20th century. Int. J. Climatol. 2007, 27, 2069-2081. [CrossRef]

51. Tomczyk, A.M. Impact of macro-scale circulation types on the occurrence of frosty days in Poland. Bull. Geogr. Phys. Geogr. Ser. 2015, 9, 55-65. [CrossRef]

52. Ptak, M.; Tomczyk, A.M.; Wrzesiński, D. Effect of teleconnection patterns on changes in water temperature in Polish lakes. Atmosphere 2018, 9, 66. [CrossRef]

53. Hurrel, J.W. Decadal trends in the North Atlantic oscillation: Regional temperatures and precipitation. Science 1995, $269,676-679$. [CrossRef] [PubMed]

54. Hurrel, J.W.; Deser, C. North Atlantic climate variability: The role of the North Atlantic Oscillation. J. Mar. Syst. 2010, 78, 28-41. [CrossRef]

55. Bednorz, E. Synoptic reasons for heavy snowfalls in the Polish-German lowlands. Theor. Appl. Climatol. 2008, 92, 133-140. [CrossRef]

56. Salmaso, N.; Cerasimo, L. Long-term trends and fine year-to-year tuning of phytoplankton in large lakes are ruled by eutrophication and atmospheric modes of variability. Hydrobiologia 2012, 698, 17-28. [CrossRef]

57. Ptak, M.; Tomczyk, A.M.; Wrzesiński, D.; Bednorz, E. Effect of teleconnection patterns on ice conditions in lakes in lowland Poland. Theor. Appl. Climatol. 2019, 138, 961-1969. [CrossRef]

58. Bueha, C.; Nakamuta, H. Scandinavian pattern and its climatic impact. Q. J. R. Meteor. Soc. 2007, 133, 2117-2131. [CrossRef]

59. Liu, Y.; Wang, L.; Zhou, W.; Chen, W. Three Eurasian teleconnection patterns: Spatial structures, temporal variability, and associated winter climate anomalies. Clim. Dyn. 2014, 42, 2817-2839. [CrossRef]

60. Nojarov, P. Circulation factors affecting precipitation over Bulgaria. Theor. Appl. Climatol. 2017, 127, 87-101. [CrossRef]

61. Degirmendžić, J. Wpływ klina Wyżu Azjatyckiego nad Skandynawią na temperature powietrza w Europie. Przegląd Geofiz. 1999, 44, 211-229.

62. Pospieszyńska, A.; Przybylak, R. Air temperature changes in Torun (central Poland) from 1871 to 2010. Theor. Appl. Climatol. 2019, 135, 707-724. [CrossRef]

63. Kolendowicz, L.; Czernecki, B.; Półrolniczak, M.; Taszarek, M.; Tomczyk, A.M.; Szyga-Pluta, K. Homogenization of air temperature and its long-term trends in Poznań (Poland) for the period 1848-2016. Theor. Appl. Climatol. 2019, 136, 1357-1370. [CrossRef]

64. Wibig, J.; Głowicki, B. Trends in minimum and maximum temperature in Poland. Clim. Res. 2002, 20, 123-133. [CrossRef]

65. Lobell, D.B.; Bonfils, C.; Duffy, P.B. Climate change uncertainty for daily minimum and maximum temperatures: A model inter-comparison. Geophys. Res. Lett. 2007, 34, L05715. [CrossRef]

66. Peng, S.; Piao, S.; Ciais, P.; Myneni, R.B.; Chen, A.; Chevallier, F.; Dolman, A.J.; Janssens, I.A.; Peñuelas, J.; Zhang, G.; et al. Asymmetric effects of daytime and night-time warming on Northern Hemisphere vegetation. Nature 2013, 501, 88-92. [CrossRef]

67. Ma, L.; Qin, F.; Wang, H.; Qin, Y.; Xia, H. Asymmetric seasonal daytime and nighttime warming and its effects on vegetation in the Loess Plateau. PLoS ONE 2019, 14, e0218480. [CrossRef]

68. Tomczyk, A.M.; Bednorz, E.; Półrolniczak, M.; Kolendowicz, L. Strong heat and cold waves in Poland in relations with the large-scale atmospheric circulation. Theor. Appl. Climatol. 2019, 137, 1909-1923. [CrossRef]

69. Czernecki, B.; Miętus, M. The thermal seasons variability in Poland, 1951-2010. Theor. Appl. Climatol. 2017, 127, 481-493. [CrossRef]

70. Czarnecka, M.; Nidzgorska-Lencewicz, J. Zmienność termicznej zimy w Polsce w latach 1960-2015. Acta Agrophys. 2017, 24, 205-220.

71. Tomczyk, A.M.; Sulikowska, A.; Bednorz, E.; Półrolniczak, M. Atmospheric circulation conditions during winter warm spells in Central Europe. Nat. Hazards 2019, 96, 1413-1428. [CrossRef]

72. Krzyżewska, A. Fale ciepła i chłodu w (V) południowo-wschodnim regionie bioklimatycznym w latach 1981-2010. Ann. UMCS Sect. B 2014, 49, 143-154.

73. Nowosad, M.; Bartoszek, K. Wieloletnia zmienność grubości pokrywy śnieżnej w okolicy Lublina. In Wahania Klimatu w Różnych Skalach Przestrzennych i Czasowych; Piotrowicz, K., Twardosz, R., Eds.; Instytut Geografii i Gospodarki Przestrzennej Uniwersytetu Jagiellońskiego: Kraków, Poland, 2007; pp. 411-421.

74. Brown, P.J.; Bradley, R.S.; Keimig, F.T. Changes in extreme climate indices for the northeastern United States, 1870-2005. J. Clim. 2010, 23, 6555-6572. [CrossRef]

75. Skaugen, T.; Stranden, H.B.; Saloranta, T. Trends in snow water equivalent in Norway (1931-2009). Hydrol. Res. 2012, 43, 489-499. [CrossRef]

76. Laternser, M.; Schneebeli, M. Long-term snow climate trends of the Swiss Alps (1931-99). Int. J. Climatol. 2003, 23, 733-750. [CrossRef]

77. Marty, C.; Meister, R. Long-term snow and weather observations at Weissfluhjoch and its relation to other high-altitude observatories in the Alps. Theor. Appl. Climatol. 2012, 110, 573-583. [CrossRef] 
78. Scherrer, S.C.; Appenzeller, C.; Laternser, M. Trends in Swiss Alpine snow days: The role of local-and large-scale climate variability. Geophys. Res. Lett. 2004, 31, L13215. [CrossRef]

79. Micu, D. Snow pack in the Romanian Carpathians under changing climatic conditions. Meteorol. Atmos. Phys. 2009, 105, 1-16. [CrossRef]

80. Bulygina, O.; Groisman, P.Y.; Razuvaev, V.; Korshunova, N. Changes in snow cover characteristics over Northern Eurasia since 1966. Environ. Res. Lett. 2011, 6, 045204. [CrossRef]

81. Marty, C.; Blanchet, J. Long-term changes in annual maximum snow depth and snowfall in Switzerland based on extreme value statistics. Clim. Chang. 2012, 111, 705-721. [CrossRef]

82. Niedźwiedź, T. Sytuacje Synoptyczne i Ich Wpływ na Zróżnicowanie Przestrzenne Wybranych Elementów Klimatu w Dorzeczu Górnej Wisty; Rozprawy Habilitacyjne Uniwersytetu Jagiellońskiego: Kraków, Poland, 1981.

83. Yarnal, B. Synoptic Climatology in Environmental Analysis; Belhaven Press: London, UK, 1993.

84. Barnston, A.G.; Livezey, R.E. Classification, seasonality and persistence of low frequency atmospheric circulation patterns. Mon. Weather. Rev. 1987, 115, 1083-1126. [CrossRef]

85. Tomczyk, A.M.; Szyga-Pluta, K.; Bednorz, E. The effect of macro-scale circulation types on the length of the growing season in Poland. Meteorol. Atmos. Phys. 2019, 131, 1315-1325. [CrossRef]

86. Wrzesiński, D.; Choiński, A.; Ptak, M.; Skowron, R. Effect of the North Atlantic Oscillation on the Pattern of Lake Ice Phenology in Poland. Acta Geophys. 2015, 63, 1664-1684. [CrossRef]

87. Vihma, T.; Graversen, R.; Chen, L.; Handorf, D.; Skific, N.; Francis, J.A.; Tyrrell, N.; Hall, R.; Hanna, E.; Uotila, P.; et al. Effects of the tropospheric large-scale circulation on European winter temperatures during the period of amplified Arctic warming. Int. J. Climatol. 2020, 40, 509-529. [CrossRef]

88. Riaz, S.M.F.; Iqbal, M.J.; Hameed, S. Impact of the North Atlantic Oscillation on winter climate in Germany. Tellus A Dyn. Meteorol. Oceanogr. 2017, 69, 1406263. [CrossRef]

89. Brown, R.D.; Petkova, N. Snow cover variability in Bulgarian mountainous regions, 1931-2000. Int. J. Climatolol. 2007, 27, 1215-1229. [CrossRef] 